\title{
SISTEM PEMBINAAN AKHLAK PESERTA DIDIK (Studi Deskriptif Sistem Pembinaan Akhlak Peserta Didik di SMAN 3 Bandung)
}

\author{
Ghina Khoirunnisa Aulya*, \\ Udin Supriadi, Agus Fakhruddin \\ Program Studi Ilmu Pendidikan Agama Islam \\ Fakultas Pendidikan Ilmu Pengetahuan Sosial, Universitas Pendidikan Indonesia \\ *Email: ghina.k.aulya@gmail.com
}

\begin{abstract}
ABSTRAK
Penelitian ini dilatarbelakangi oleh permasalahan yang terjadi yaitu merosotnya akhlak remaja yang ditandai dengan pergaulan bebas, minuman keras, narkoba dan lain sebagainya. Untuk mengatasi kemerosotan akhlak, maka diperlukan pembinaan akhlak secara terus-menerus yang terintegrasi dalam pendidikan sekolah. Mengingat tujuan dari pendidikan itu sendiri salah satunya adalah membentuk akhlakpeserta didik. Penelitian ini bertujuan untuk mengetahui (1) profil SMAN 3 Bandung (2) raw input peserta didik di SMAN 3 Bandung (3) instrumental input pembinaan akhlak peserta didik di SMAN 3 Bandung (4) process pembinaan akhlak peserta didik di SMAN 3 Bandung (5) output pembinaan akhlak peserta didik di SMAN 3 Bandung. Penelitian ini menggunakan pendekatan kualitatif dengan metode deskriptif. Pengumpulan data dilakukan melalui observasi, wawancara, dan studi dokumen. Berdasarkan hasil penelitian diperoleh gambaran mengenai raw input peserta didik yang dilakukan di SMAN 3 Bandung melalui penyeleksian hasil NEM atau passing grade dan kualitas minat bakat. Adapun instrumental input pembinaan akhlak di SMAN 3 Bandung, menggunakan metode pembiasaan, keteladanan dan memperhatikan psikologis sasaran yang akan dibina. Materi yang disampaikan meliputi tema alQur'ān (tahsin, hapalan al-Qur'ān, akhlak), fiqh, asmaul husna, akhlak terpuji, hukum Islam, dan keteladan Rasūl Allah SAW, Ibadah wajib, dakwah. Pemateri dalam pembinaan akhlak diantaranya para alumni, guru PAI, dan pemateri dari PUSDAI (Pusat Dakwah Islam) Bandung. Adapun program pembinaan akhlak di SMAN 3 Bandung, dibagi ke dalam beberapa kegiatan: kegiatan harian: tadarusan, budaya 7S (Senyum, Sapa, Salam, Sopan, Santun, Sigap, Semangat). Kegiatan mingguan: MT-PAI (Mentoring Terintegrasi-PAI), keputrian, şalat jum'at berjam'ah. Kegiatan bulanan: kajian Islam. Kegiatan tahunan: SANLAT (Pesantren Kilat), penyembelihan hewan qurban, dan manasik haji. Hasil dari pembinaan akhlak di SMAN 3 Bandung cukup berhasil, hal itu dapat dilihat dari adanya perubahan secara aspek kognitif dan aspek afektif peserta didik selama proses pembinaan.
\end{abstract}

Kata Kunci: Akhlak, Pembinaan, Peserta Didik, Sistem. 


\section{PENDAHULUAN}

Pendidikan merupakan sesuatu yang sangat penting dalam kehidupan manusia. Dalam kenyataannya, pendidikan telah mampu membawa manusia ke arah kehidupan yang lebih beradab. Pendidikan telah ada seiring dengan lahirnya manusia. Ketika manusia muncul, di ranah itu pula pendidikan pun muncul. Selain itu, pendidikan juga merupakan investasi yang paling utama bagi bangsa, apalagi bagi bangsa yang sedang berkembang. Pembangunan hanya dapat dilakukan oleh manusia yang dipersiapkan melalui pendidikan (Somarya \& Nuryani, 2010, hlm. 26).

Pendidikan sebagai sebuah bentuk kegiatan manusia dalam kehidupannya menempatkan tujuan sebagai sesuatu yang hendak dicapai, baik tujuan yang dirumuskan itu bersifat abstrak atau yang dibentuk secara khusus untuk memudahkan pencapaian tujuan. Penyelenggaraan pendidikan di Indonesia menurut UU No. 20 tahun 2003 bab II pasal 3 tentang fungsi dan tujuan pendidikan nasional bahwa pendidikan nasional berfungsi mengembangkan kemampuan dan membentuk watak serta peradaban bangsa yang bermartabat dalam rangka mencerdaskan kehidupan bangsa bertujuan untuk berkembangnya potensi peserta didik agar menjadi manusia yang beriman dan bertakwa kepada Tuhan Yang Maha Esa, berakhlak mulia, sehat, berilmu, cakap, kreatif, mandiri dan menjadi warga negara yang demokratis serta bertanggungjawab. Kita dituntut mengupayakan konsep-konsep baru yang sesuai dengan kebutuhan zaman, untuk meningkatkan akhlak peserta didik (Pidarta, 2011, hlm. 9).

Pada bidang keagamaan, tujuan pendidikan pun lebih dikembangkan lagi. Perubahan keempat UUD 1945 pasal 31 ayat (3) disebutkan, pemerintah mengusahakan dan menyelenggarakan satu sistem pendidikan nasional, yang meningkatkan keimanan dan ketakwaan serta akhlak mulia dalam rangka mencerdaskan kehidupan bangsa, yang diatur dengan undang-undang (Rahmat, 2012, hlm. 2). Berdasarkan uraian di atas, maka terdapat beberapa potensi yang diharapkan dimiliki oleh setiap peserta didik setelah menempuh suatu proses pendidikan, yang salah satunya adalah memiliki akhlak mulia.

Antara akhlak dengan ilmu pendidikan memiliki hubungan yang mendasar dalam hal teoritik dan pada tatanan praktisnya. Sebab, dunia pendidikan sangat besar sekali pengaruhnya terhadap perubahan perilaku, akhlak seseorang. Berbagai ilmu diperkenalkan, agar siswa memahaminya dan dapat melakukan suatu perubahan pada dirinya (Zahruddin, 2004, hlm. 59).

Pendidikan akhlak dalam pengertian Islam adalah bagian yang tidak dapat dipisahkan dari pendidikan agama. Sebab yang baik adalah yang dianggap baik oleh agama dan yang buruk adalah yang dianggap buruk oleh agama. Sehingga seorang muslim tidak sempurna agamanya bila akhlaknya tidak baik. Hampir sepakat filosof-filosof pendidikan Islam, bahwa pendidikan akhlak adalah jiwa pendidikan Islam. Sebab pendidikan akhlak adalah jiwa pendidikan Islam karena salah satu tujuan tertinggi pendidikan Islam adalah pembinaan akhlaq al-karimah (Ramayulis, 2005, hlm. 72).

Akan tetapi melihat kondisi di Indonesia, yang menjadi persoalan pendidikan agama Islam salah satunya adalah merosotnya akhlak remaja. Berdsarkan hasil survey pada Kompasiana bahwa $62,7 \%$ remaja SMP/SMA mengaku sudah pernah melakukan hubungan seks pranikah dan $21,2 \%$ dari siswi-siswi tersebut pernah melakukan aborsi ilegal. Hal yang lebih mengkhawatirkan adalah bahwa yang melakukan tindak amoral tidak sedikit 
dari pelajar yang sejatinya mereka sedang mengenyam pendidikan di mana memiliki tujuan salah satunya adalah meningkatkan akhlak bangsa. Fenomena tersebut bisa kita lihat dari media, pada Oktober 2013 lalu (Oemar, 2013) pelajar di Jakarta membajak bus umum. Dan masih banyak lagi kriminalitas yang dilakukan oleh kaum pelajar diantaranya: tawuran antar pelajar, narkoba pergaulan bebas, kebut-kebutan di jalan, menjamurnya geng motor yang beranggotakan remaja usia sekolah.

Hal-hal di atas menunjukkan melorotnya akhlak generasi bangsa. Memang, kita tidak bisa menyalahkan sekolah atau pendidikan dalam hal tindakan amoral atau kriminalitas yang dilakukan pelajar, kita sadari banyak yang mempengaruhi terkait sikap yang dilakukan pelajar tersebut. Seperti lingkungan, pendidikan keluarga dll. Seperti yang di kemukakan Eva Zelner psikolog anak dari Zurich, bahwa orang tua sekarang telah menukarkan cinta dengan cara menuruti apa saja yang diminta anaknya, sementara waktu di mana anak-anak boleh merasakan kasih sayang orang tua terabaikan, seluruh waktunya dihabiskan untuk pekerjaan, aktivitas dan karier mereka (Suprapto, 2012).

Menurut Bloom (dalam Tafsir 2008, hlm. 15) tiga segi utama pembinaan dibagi yaitu: pembinaan jasmani, kesehatan dan keterampilan (ranah psikomotor), pembinaan akal (ranah kognitif) dan pembinaan hati (ranah afektif). Menyoroti perpindahan kepada kurikulum 2013, bahwa pengembangan kurikulum 2013 akan menghasilkan insan Indonesia yang: produktif, krearif, inovatif, afektif; melalui pengamatan sikap, keterampilan, dan pengetahuan yang terintegrasi. Dilihat dari segi fungsi pendidikan tersebut, setiap pembinaan haruslah berfungsi dalam seluruh aspek kepribadian anak didik. Dalam kurikulum
2013, difokuskan pada pembentukan kompetensi dan karakter peserta didik (lebih kepada ranah afektif) (Mulyasa, 2013, hlm. 65).

Di sisi lain, Komarudin Hidayat dalam Muhaimin (2004, hlm. 90) menyoroti orientasi pendidikan agama Islam yang selama ini berjalan di sekolah dianggapnya kurang tepat. Sebagai indikator kekurangtepatan itu adalah pendidikan agama saat ini lebih berorientasi pada belajar terntang agama sehingga hasilnya banyak orang yang mengetahui nilai-nilai ajaran agama, tetapi perilakunya tidak relevan dengan nilai-nilai ajaran yang diketahuinya. Orientasi yang semacam itu, menyebabkan terjadinya keterpisahan dan kesenjangan antara ajaran agama dan realitas perilaku pemeluknya.

Pembinaan agama Islam dalam hal ini untuk pembentukan akhlak tidak hanya oleh lingkungan keluarga atau masyarakat tetapi menjadi satu kesatuan yang saling mempengaruhi ke tiga lingkungan tersebut agar terwujud keselarasan dan kesatuan tindak dalam pembinaannya.

Akan tetapi sebagian kelembagaan masyarakat seperti keluarga, masjid, dan lingkungan yang mengelola pendidikan agama Islam untuk generasi muda, sudah mulai mengendor dalam melaksanakan tanggungjawabnya. Karena itu di atas pundak sekolahlah tertumpu beban yang berat untuk mengajarkan pendidikan agama, karena merupakan satu-satunya lembaga yang mengumpulkan semua anak rakyat dalam waktu yang sepanjang mungkin (Ahmad, 2008, hlm. 38). Sehingga sekolah dalam hal ini yang bertanggung jawab dalam mengupayakan terwujudnya cita-cita atau tujuan dari pendidikan itu sendiri. Adelina Hasyim dalam Tesis (1998) Rahmat (2012, hlm. 5), mengemukakan tentang tindakan pelanggaran etis menemuakan, bahwa sekolah-sekolah yang kaya dengan nuansa dan pembelajaran agama 
berpengaruh positif terhadap perilaku moral para siswanya. SMA Negeri 3 Bandung merupakan Sekolah Menengah Atas yang sangat terpandang di Kota Bandung, sekolah ini dicap sebagai sekolah terbaik di kota kembang. Sehingga sangat menarik untuk diteliti mengenai sistem pembinaan akhlak yang ada di SMA Negeri 3 Bandung.

\section{METODE}

Dalam penelitian ini, peneliti menggunakan desain penelitian desain case study. Desain case study menurut Nasution (2009, hlm. 25) adalah bentuk penelitian yang mendalam tentang suatu aspek lingkungan social termasuk manusia di dalamnya. Case study dapat dilakukan terhadap seorang individu, sekelompok individu (misalnya suatu keluarga), segolongan manusia (guru, suku Minagkabau), lingkungan hidup manusia atau lembaga sosial. Dalam penelitian ini, penelitian terhadap lembaga Sekolah Menengah Atas Negeri 3 Bandung.

Pendekatan yang penulis gunakan dalam penelitian ini adalah kualitatif yakni suatu pendekatan penelitian yang mengungkap situasi sosial tertentu dengan mendeskripsikan kenyataan (Sugiyono, 2013, hlm. 15). Metode yang digunakan adalah deskriptif. Menurut Sukardi(2013, hlm. 157) penelitian deskriptif merupakn metode penelitian yang berusaha menggambarkan dan menginterpretasi objeksesuai dengan apa adanya.

Adapun yang menjadi partisipan pada penelitian ini adalah kepala sekolah/ wakil kepala sekolah bidang kurikulum SMA Negeri 3 Bandung, guru Pendidikan Agama Islam SMAN 3 Bandung, Tutor Mentoring (para alumni SMAN 3 Bandung) dan beberapa siswasiswi kelas X SMA Negeri 3 Bandung.

Teknik pengumpulan data yang peneliti gunakan diantaranya wawancara, observasi dan studi dokumentasi.Adapun tahapan analisis data yang dilakukan penelitian adalah dengan mereduksi data dengan memilih data yang dibutuhkan serta dikategorikan dengan koding. Data hasil reduksi disajikan dalam display data dengan uraian singkat secara deskriptif dan kemudian disimpulkan.

\section{HASIL DAN PEMBAHASAN}

\section{Profil Sekolah}

\section{a. Sejarah dan latar belakang SMA Negeri 3 Bandung \\ Sekolah Menengah Atas Negeri 3} Bandung berdiri sejak tahun 1953 SMA Negeri 3 Bandung dikenal dengan sebutan SMA Belitung karena berlokasi di jalan Belitung No. 8 Bandung. Sekolah ini dibangun di atas tanah hasil hibah HBS V untuk digunakan bersama SMA Negeri 5 Bandung termasuk gedung + lapangan olahraga di Jalan Bali. SMAN 3 menempati lokasi bangunan sebelah barat sedang SMAN 5 menempati lokasi sebelah timur. Adapun luas tanah SMAN 3 Bandung adalah $7120 \mathrm{~m} 2$ dan luas bangunannya adalah $5340 \mathrm{~m} 2$. Bangunan sekolah ini merupakan gedung tua yang dibangun pada zaman pemerintahan Hindia-Belanda (tahun 1916), dirancang oleh arsitek C. P Schoemaker. Yang berfungsi sebagai gedung HBS (Hoogere Burgerschool) yaitu sekolah untuk anakanak belanda golongan menengah (Dok.8)

Adapun batas SMA Negeri 3 dan SMA Negeri 5 hanya dibatasi oleh jalur koridor tengah yang memanjang dari arah utara ke selatan. Batas koridor ini dapat juga berfungsi sebagai pemersatu antara SMA 3 dan SMA 5 sehingga para warga kedua sekolah ini dapat hidup berdampingan dengan rukun dan damai. Diantara para siswa pun tidak pernah terjadi perselisihan (Dok.8).

\section{b. Visi dan Misi SMAN 3Bandung}

SMA Negeri 3 menerapkan menerapkan manajemen 1567 . Di mana angka-angka tersebut memiliki makna 
tertentu, berikut adalah penjelasannya: Angka satu mewakili visi, yaitu menjadi sekolah berbasis riset terdepan dalam pembentukan karakter berwawasan lingkungan unggul dalam imtak dan iptek.Visi tersebut merupakan landasan statregik dalam meningkatkan mutu pendidikan di SMA Negeri 3 Bandung. Seperti yang dikemukakan oleh Usman (2010, hlm. 70), visi sekolah dijadikan sebagai cita-cita bersama warga sekolah/madrasah dan segenap pihak yang berkepentingan pada masa yang akan datang, dan mampu memberikan inspirasi, motivasi dan kekuatan pada warga sekolah dan segenap pihak yang berkepentingan.

Angka lima mewakili misi, yaitu membangun SDM yang unggul dalam Imtak dan Iptek sesuai dengan dinamika globalisasi, mewujudkan pendidik, tenaga kependidikan dan peserta didik yang memiliki integritas, mewujudkan lulusan yang berkarakter dan berwawasan kebangsaan, serta peduli terhadap lingkungan hidup, mengembangkan potensi kecerdasan intelektual, emosional dan spiritual guna memberikan solusi terhadap dinamika permasalahan bangsa dan Negara, menjalin kemitraan dengan stakeholders (pemangku kepentingan) melalui peningkatan pelayanan prima, transparan dan akuntabel guna membangun komunikasi yang harmonis dengan mitra kerja secara formal dan non formal.Misi yang dirumuskan pihak sekolah, telah sesuai dengan criteria yang dikemukakan oleh (Usman, 2010, hlm. 71),yaitu misi memberikan arah dalam mewujudkan visi, menjadi dasar program pokok sekolah (termasuk program pembinaan akhlak, mengacu pada misi yang pertama), menekankan pada mutu layanan peserta didik dan mutu lulusan yang diharapkan oleh sekolah.

Angka enam mewakili kebijakan mutu, meliputi: tenaga pendidik dan kependidikan, meningkatkan mutu peserta didik, meningkatkan mutu sarana pendidikan dan lingkungan sekolah, meningkatkan mutu lulusan, meningkatkan mutu sistem manajemen sekolah, meningkatkan mutu pelayanan. Angka tujuh mewakili kompetensi, meliputi : Kompetensi IMTAK (Iman dan Takwa), kompetensi IPTEQ, kompetensi kepemimpinan, kompetensi social dan kewirausahaan, kompetensi lingkungan hidup, kompetensi olahraga dan kesenia, dan kompetensi komunikasi (WKS).

Tujuh kompetensi itu untuk membina karakter, karena motto dari SMA Negeri 3 Bandung adalah : knowledge is power but character is more, yaitu ilmu penting, akan tetapi pembentukan karakter jauh lebih penting. Sehingga pengembangan motto dilakukan melalui tujuh kompetensi siswa dalam upaya membentuk karakter dan kultur sekolah. Adapun pembinaan akhlak berada di point pertama kompetensi, yaitu kompetensi Imtak (Iman dan Takwa) (WKS).

Selain itu, SMAN 3 Bandung juga menerapkan strategi segitiga sama sisi salah satu upaya mendukung kegiatan pembinaan di SMAN 3 Bandung agar tetap berkualitas dan berjaya. Adapun keterangan dari segitiga sama sisi adalah

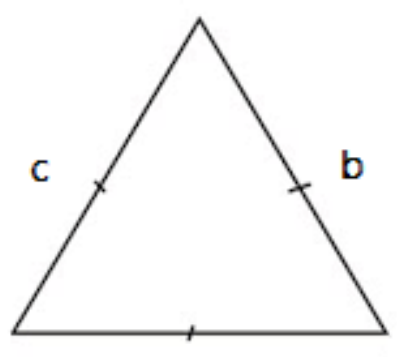

a

\section{Gambar 4.1 Strategi Manajemen}

a. Alas, adalah program jangka panjang, jangka menengah, dan jangka pendek. Seperti dalam pembinaan terdapat program harian, program bulanan, tahunan.

b. Komite Sekolah, adalah yang bertugas menggali sumber dana mendukung program yang 
ditetapkan sekolah (termasuk program pembinaan). Mengingat dana adalah salah satu unsur penting dalam terlaksananya semua program.

c. Alumni/IKA SMA3, yang ikut mendukung program sekolah. Jika belum cukup dana dari komite. Maka alumni ikut membantu (WKS).

\section{Raw Input Peserta Didik di SMA Negeri 3 Bandung}

Penerimaan peserta didik di SMA Negeri 3 Bandung dibagi ke dalam dua jalur. Jalur pertama, jalur akademik. Penerimaan peserta didik baru di SMA Negeri 3 Bandung pada jalur akademik dilaksanakan berdasarkan nilai NEM murni dengan berdasar pada passing grade. Prosentase jalur akademik ini 70\% dari jumlah kuota yang disediakan SMA Negeri 3 Bandung. Adapun kuota yang disediakan SMA Negeri 3 Bandung ini adalah 324 siswa. Jalur kedua, adalah jalur non-akademik, prosentasi jalur nonakademik $30 \%$ dari kuota yang disediakan, pembagiannya $10 \%$ untuk jalur prestasi dan 20\% untuk jalur SKTM atau jalur tidak mampu. Hanya saja untuk jalur SKTM dibatasi radius, sehingga yang diterima hanya yang berada di kota Bandung dan itu pun yang terdekat dengan lokasi SMAN 3 Bandung (WKS).

Memang secara teori Wahyuni (2008, hlm. 19) mengemukakan faktorfaktor yang mempengaruhi hasil belajar dibedakan atas dua kategori, yaitu faktor internal dan faktor eksternal. Faktor internal meliputi: faktor fisiologis dan faktor psikologis. Faktor fisiologis adalah faktor yang berhubungan dengan kondisi fisik individu. Faktor psikologis adalah keadaan psikologis yang dapat memengaruhi proses belajar. Faktor psikologis yang utama mempengaruhi proses belajar adalah kecerdasan siswa, motivasi, minat, sikap, dan bakat.

Dalam raw inputnya di SMAN 3 Bandung ini, memang tidak secara langsung aspek perilaku dijadikan indikator kelulusan. Tetapi sebenarnya secara tidak langsung penjaringan akhlak peserta didik telah dilakukan di SMP masing-masing, karena dengan lulusnya peserta didik dari SMP-nya masingmasing, hal itu menunjukkan ia minimal mempunyai predikat baik untuk akhlakul karimahnya. Paling tidak mata pelajaran PAI, PKn nya minimal baik yaitu 7,5. Sebab jika penyaringan akhlak di SMA, memang sedikit sulit (WKS).

Akhlak itu sendiri belum secara langsung menjadi indikator penerimaan peserta didik baru di SMAN3 Bandung ini, karena sistem pada tiap-tiap sekolah seperti itu sudah di atur pemerintah. Sehinga SMA Negeri 3 Bandung harus melaksanakan aturan pemerintah, sesuai dengan jurprak, jurdis. Tidak bisa serta merta SMAN 3 Bandung membuat aturan sendiri khawatir kurang baik (WGP1, WGP2, WGP3).

Selain itu, dilihat dari latar belakang SMP siswa-siswi yang diterima di SMANegeri3 Bandung berdasarkan data yang diperoleh dari wawancara dengan staff TU, kebanyakan dari sekolah elit seperti SMPN 5, SMPN 2, SMPN 2, SMP taruna bakti dan SMP darul hikam. Mengingat SMAN 3 Bandung ini memiliki passing grade tertinggi penerimaan peserta didik baru di kota Bandung.

\section{Instrumental Input Pembinaan Akhlak di SMA Negeri 3 Bandung}

\section{a. Kurikulum atau materi}

Kurikulum yang digunakan dalam pembinaan akhlak peserta didik di SMA Negeri 3 Bandung ini (khusunya untuk program Mentoring Terintegrasi PAI (MT PAI) ini disesuaikan dengan silabus mata pelajaran PAI pada semester 1, 
mencakup tema al-Qur'ān (tahsin, hapalan al-Qur'ān, akhlak), asmaul husna, akhlaq terpuji, hukum islam, dan keteladan Rasūl Allah SAW (Dok.3, WGP2).

Sedangkan materi pada sanlat, diserahkan kepada pihak pesantren tidak ada campur tangan dari pihak sekolah. Dari sekolah hanya mengetahui apa saja yang diajarkan, dan kegiatan apayang diikuti kemudian menyerahkan peserta didik kepada pihak pesantren. Pesantren al-Qur'ān Babussalam adalah pesantren yang mendalami al-Qur'ān sehingga memang pemberian materi lebih ditekankan kepada pembelajaran alQur'ān, penghafalan Al-Qur'ān, cara membaca al-Qur'ān. Sedangkan pada program manasik haji materi yang diajarkan mengenai tata cara Haji tamattu secara berurutan sesuai tuntunan alQur'ān dan al-Hadis (WWKs, WGP1).

\section{b. Metode}

Metode menjadi bagian yang berperan penting dalam mencapai tujuan. Adapun metode yang digunakan di dalam pembinaan akhlak peserta didik di SMA Negeri 3 adalah pembiasaan. Dalam pembiasaan ini ada kegiatan harian, kegiatan mingguan, kegiatan bulanan dan kegiatan tahunan. Adapun kegiatan harian: Tadarus atau hafalan bersama setiap kelas, 7S. Kegiatan mingguan : Şalat Jumat berjamaah untuk para siswanya, sedangkan untuk putrinya ada keputrian. Kegiatan bulanan : Kajian Islam. Kegiatan Tahunan : Pesantren Kilat, Pengelolaan Hewan Qurban, Manasik Haji (WKS, WGP1, WGP2, WGP3).

Ada satu program pembinaan unggulan di SMA Negeri 3 Bandung ini yaitu Program Mentoring Terintegrasi PAI (MT PAI) SMAN 3 Bandung. Program Mentoring Terintegrasi PAI (MT PAI) adalah program mentoring wajib untuk seluruh siswa yang mengambil mata pelajaran PAI pada semester 1. Program ini merupakan pengembangan dari pembelajaran PAI yang hanya 2 jam pelajaran (90 menit) setiap pekannya di ruang kelas. Program ini dilaksanakan selama 1 semester yaitu pada semester ganjil (WGP1, Dok.3).

Adanya kegiatan MT PAI ini, pihak sekolah ingin mengemas materi supaya tidak boring atau membosankan untuk siswa-siswi. Berharap materi itu dapat dikemas dengan metodologi yang bisa membuat siswa-siswi enjoy dan happy. Sehingga pada pelaksanaanya pembinaan dalam mentoring ini terdapat simulasi, game, kisah-kisah (WGP1, WGP2, WGP3,Dok.3).

Selain itu metode lainnya adalah metode keteladanan. Metode keteladan dikhususkan untuk kepala sekolah, para pendidik di SMA Negeri 3 Bandung. Kepala sekolah dan pendidik harus menjadi tauladan atau uswah bagi peserta didik dalam segala hal seperti dalam kedisiplinan, dalam bertutur kata, dalam penampilan dll. Inilah yang paling berat, jika hal ini sudah bisa dianut maka pembinaan berhasil. Oleh karena itu, hal ini menjadi tanggung jawab kepala sekolah dan pendidik, sebelum membina peserta didik, terlebih dahulu dibina akhlaknya sendiri (WKS, WGP1).

Memang secara keseluruhan, metode yang lebih banyak digunakan dalam pembinaan akhlak di SMAN 3 Bandung adalah metode ceramah, kemudian drill (praktek) seperti pada program penyembelihan hewan qurban dan manasik haji (WGP2, WKS).

Metode pembinaan akhlak yang digunakan SMA Negeri 3 Bandung telah sesuai dengan teori yang dikemukakan oleh Nata (2003, hlm. 164), salah satu metode yang dapat ditempuh dalam pembinaan akhlak adalah pembiasaan. Kemudian cara atau metode lain dalam pembinaan akhlak adalah melalui keteladan. Pembinaan akhlak secara efektif dapat pula dilakukan dengan memperhatikan faktor kejiwaan sasaran 
yang akan dibina. Menurut hasil penelitian para psikolog bahwa kejiwaan manusia berbeda-beda menurut perbedaan tingkat usia (Nata, 2003, hlm. 166).

\section{c. Pendidik}

Dalam program MT PAI (Mentoring Terintegrasi PAI), yang membina adalah pementor. Sehingga pementor adalah salah satu komponen yang berperan penting dalam mencapai tujuan pembinaan. Mentor adalah alumni SMAN 3 Bandung atau siswa yang telah ditunjuk Guru PAI SMA Negeri 3 Bandung yang mempunyai keterampilan membina dan berkomitmen terhadap program MT-PAI. Program MT PAI bekerjasama dengan DKM SMA 3 dalam pengelolaan mentor. Dalam rangka meningkatkan kualitas pe-mentor, maka diadakan sekolah mentor untuk para mentor yang akan membina dalam program MT-PAI (Dok. 3, WP).

Kemudian yang memberikam materi dalam kegiatan manasik haji adalah pembina dari pihak PUSDAI, dikarenakan dalam pelaksanaan kegiatan manasik haji ini, pihak sekolah bekerjasama dengan pihak PUSDAI (WGP1, WGP3). Demikian pula pada program manasik haji, karena pihak sekolah bekerjasama dengan pihak pesantren al-Qur'ān Babussalam dan menyerahkan peserta didik kepada pihak pesantren untuk kemudian mengikuti serangkaian kegiatan yang ada di Pesantren seperti ceramah, pendalaman materi al-Qur'ān dan penghafalan alQur'ān semua pembina berasal dari pihak pesantren (WGP3, WWKs).

\section{Proses Pembinaan Akhlak Peserta Didik di SMA Negeri 3 Bandung}

Berdasarkan hasil wawancara dengan dan kepala sekolah dan para guru PAI mengatakan bahwa tujuan dari pembinaan akhlak ini adalah meningkatkan iman takwa peserta didik. Sehingga harapannya peserta didik di SMAN 3 Bandung tidak hanya pintar akan tetapi shaleh dan shalehah.

Untuk itu, pembinaan akhlak peserta didik di SMA Negeri 3 Bandung, dimulai setelah peserta didik diterima menjadi siswa-siswi baru di SMA Negeri 3 Bandung, penyeleksian penerimaan peserta didik baru sesuai dengan kriteria kelayakan yang diatur SMAN 3 Bandung. Pembinaan diawali dengan program Mentoring Terintergrasi PAI (MT-PAI) yang wajib diikuti seluruh siswa kelas $\mathrm{X}$, dilaksanakan satu semester yaitu pada semester ganjil. Mentoring adalah sebuah pembinaan yang dilakukan dalam sebuah kelompok kecil. Mentoring dapat digunakan sebagai sarana mengkaji nilai-nilai agama Islam yang dikemas dalam bentuk kegiatan aplikatif-kreatif. Mentoring dipandu dan dibimbing oleh seorang mentor di mana mentor tersebut merupakan senior sehingga proses bimbingan yang dilakukan akan lebih terarah dan tepat sasaran (WGP1, WGP2, WGP3, Dok.3).

Adapun proses pembinaan pada program mentoring alurnya adalah sebagai berikut: mentoring dilakukan setiap seminggu sekali (pada hari Jum'at) mulai pukul 13.00-15.00.Setiap mentor yang akan membina dibekali Handbook Kaka Mentor (KAMEN). Handbook kamen berisi tentang adab pelaksanaan mentoring, diantaranya: ada untuk diri sendiri, adab dalam forum mentoring, adab terhadap adik mentor. Selain itu terdapat SOP Mentoring untuk kamen (kaka mentor), materi dan simulasi. Adapun SOP mentoring adalah sebagai berikut: menyiapkan materi sebelum mentoring, memakai name tag saat kegiatan mentoring, menanyakan kabar adik mentor, mengisi daftar hadir mentor, mengedarkan presensi adik mentor, mengirimkan sms tausyiah setiap minggu, membenarkan bacaan al-Qur'ān adik mentor (WP, Dok.8). 
Kemudian pembinaan dilanjutkan dengan kegiatan pembiasaan. Adapun pembiasaan dibagi menjadi kegiatan harian, kegiatan mingguan, kegiatan bulanan dan kegiatan tahunan.

Kemudian pembinaan dilanjutkan dengan kegiatan pembiasaan. Adapun pembiasaan dibagi menjadi kegiatan harian, kegiatan mingguan, kegiatan bulanan dan kegiatan tahunan.

\section{a. Kegiatan harian}

Setiap hari sebelum mengawali jam pelajaran pertama melakukan doa bersama, kemudian tadarus al-Qur'ān. Pembiasaan tadarusan ini, adalah bentuk upaya sekolah agar peserta didik terbiasa untuk berinteraksi dengan al-Qur'ān. Tadarus dibimbing oleh rohis kelas masing-masing dengan pengawasan guru yang bersangkutan (guru pada awal pelajaran). Setelah tadarusan selesai, Surat dan ayat dicatat pada agenda tadarusan yang disediakan untuk setiap kelasnya dan ditanda tangani guru yang mengawas. Biasanya waktu yang diperlukan rata-rata 5-10 menit dan peserta didik yang meminta kepada guru untuk tadarus al-Qur'ān, itupun dilakukan bervariasi tergantung setiap kelas. Ada yang melakukannya dengan menyambung sehingga mereka setiap harinya meneruskan ayat dari hari sebelumnya (WGP1, WGP2, WGP3).

Pembiasaan 7S (Senyum, Sapa, Salam, Sopan, Santun, Sigap dan Semangat) menjadi budaya siswa-siswi SMAN 3 Bandung setiap hari bahkan tidak hanya oleh peserta didik terhadap gurunya. Akan tetapi guru pun juga ikut membudayakannya, itu tidak hanya dilakukan sesama guru tetapi oleh guru kepada peserta didik sebagai tauladan kepada siswa-siswinya. Bahkan guru tidak merasa gengsi jika harus terlebih dahulu memberikan salam kepada siswasiswinya. Saat penulis observasi, penulis melihat banyak peserta didik yang sangat sopan saat berinteraksi dengan gurunya. Ketika mereka ke ruang guru untuk menemui guru, mereka melakukannya dengan sangat santun, memberikan salam. Selain itu mereka tidak sungkan untuk berkeluh kesah dan memberikan pendapatnya ketika terjadi masalah. Saat penulis sedang berada di ruang wakil kepala sekolah, ada dua orang murid yang berinteraksi dengan wakil kepala sekolah untuk menyampaikan masalah yang terjadi mengenai perpindahan kelas. Mereka menyampaikannya dengan sopan, dan guru pun memberikan penjelasannya dengan baik kepada siswanya yang akhirnya mereka menerima kebijakan yang disampaikan gurunya (WGP1, WGP2, O2).

\section{b. Kegiatan mingguan}

Seluruh siswa yang kelas X, XI dan XII diwajibkan untuk sholat jumat berjama'ah di mesjid. Adapun yang menjadi imam Şalat jumatnya adalah kepala sekolah. Ini menjadi salah satu bentuk keteladan dari pimpinan kepada semua warga sekolah baik guru ataupun peserta didik. Bagaimana pun untuk mengajari siswa supaya berakhlak mulia harus dengan keteladan dari para pengajarnya (WGP1).

Keputrian merupakan salah satu kegiatan yang dilaksanakan khusus untuk para siswa perempuan. Kegiatan ini dilaksanakan setiap hari Jum'at untuk seluruh siswi kelas X, XI dan XII, dimulai pukul 11.00 sampai dengan pukul 12.00. kegiatan ini bertepatan dengan kegiatan Şalat Jum'at yang dilakukan oleh siswa laki-laki. Metode yang digunakan dalam kegiatan ini adalah mentoring atau tutorial.

\section{c. Kegiatan tahunan}

Pembiasaan ini dilakukan setiap tahun dalam rangka memperingati hari besar Islam. Teknisnya menghimbau kepada seluruh orang tua siswa-siswi, bilamana ada yang ingin menitipkan hewan qurban untuk disembelih di sekolah kemudian akan didistribusikan kepada masyarakat yang layak untuk 
menerimanya. Semua warga sekolah ikut terlibat di dalam kegiatan ini. Pada pelaksanaanya $78 \%$ panitia menghadiri dan mengikuti rangkaian acara sampai selesai. $70 \%$ kegiatan dapat dilaksanakan dengan lancar, 60\% masyarakat sekitar menghadiri acara dan 90\% pendistribusian daging qurban kepada mustahiq dapat disalurkan (Dok.4).

Ujian praktik manasik Haji wajib dilaksanakan sesuai intruksi dari Kementrian Agama sehingga kegiatan manasik ini menjadi kegiatan keagamaan rutin setiap tahun. Meskipun di dalam kurikulum 2013 pembahasan bab Haji ini tidak tersurat pada materi kelas $\mathrm{X}$ tetapi tetap diimplementasikan dalam bentuk ujian praktek pada kelas XII. Adapun tujuan dari kegiatan praktek manasik haji adalah : peserta didik memahami serta mampu memperagakan tata cara Haji tamattu secara berurutan sesuai tuntunan al-Qur'ān dan al-Hadits, peserta didik dapat menghayati makna ibadah Haji serta mampu mengaplikasikannya dalam kehidupan sehari-hari, meningkatkan kualitas dan kreativitas siswa, meningkatkan motivasi peserta didik untuk melaksanakan ibadah Haji dan Umrah, mengkondisikan siswa dalam menyebarluaskan syiar Islam di lingkungan SMA Negeri 3 (Dok.2).

Pelaksanaan praktek manasik haji ini beberapa tahun terkahir, SMAN 3 Bandung bekerjasama dengan PUSDAI provinsi Jawa Barat karena dengan keterbatasan peralatan di SMAN 3 Bandung. Sebelum kerjasama sebenarnya pelaksanaannya mandiri dilakukan oleh SMAN 3 Bandung sendiri, dengan meminjam peralatan kepada yayasanyayasan tertentu. Hanya saja yayasanyayasan tersebut sudah tidak bisa lagi meminjamkannya. Sehingga dibuat solusi untuk bekerja sama dengan PUSDAI JABAR (WGP1, Dok.2).

Kegiatan ini khusus dilakukan pada bulan Ramadhan, kegiatan ini bertujuan untuk meningkatkan kecerdasan spiritual siswa dan meningkatkan jiwa sosial siswa. Semua siswa dan guru telibat dalam kegiatan ini. Program ini diwajibkan untuk kelas sepuluh. Untuk tempat pelaksanaannya di Pesantren Babussalam. Pelaksanaannya selama 3 hari 2 malam didampingi oleh guru. Siswa-siswi kelas sepuluh diserahkan kepada pihak pesantren untuk kemudian mengikuti seluruh rangkaian kegiatan yang ada di pesantren, mulai ceramah, pendalaman materi al-Qur'ān, penghafalan al-Qur'ān dan semua kegiatan-kegiatan di Pesantren. Sehingga harapannya setelah mengikuti acara Pesantren Kilat siswa-siswi SMA negeri 3 Bandung menjadi lebih baik bacaan alQur'ānnya, kemudian menambah pengalaman berada di lingkungan pesantren dan lebih memperhatikan sikap atau perilakunya supaya menjadi lebih baik (WWKs).

Pada aspek proses pembinaan ini yang tak kalah penting adalah, evaluasi. Berdasarkan wawancara yang dilakukan oleh penulis, evaluasi setiap program selalu dilakukan. Pada program tadarusan, evaluasi dilakukan setiap hari oleh guru jam pelajaran pertama, dengan menandatangani form tadarusan alQur'ān tetapi berdasarkan observasi dan wawancara kepada peserta didik yang dilakukan penulis, hal itu tidak berjalan dengan baik karena form tadarusan tidak dipakai bahkan form ada yang hilang. Alhasil mereka menuliskannya di handphone, atau buku tulis (WS1,WS2, WS3).

Senada dengan pendapat Nata (2003, hlm. 160) dalam buku Akhlak Tasawuf dijelaskan proses pembinaan akhlak dalam Islam terintegrasi dengan pelaksanaan rukun iman. Hasil analisis Muhammad al-Ghazali terhadap rukun Islam yang lima telah menunjukkan dengan jelas bahwa dalam rukun Islam terkandung konsep pembinaan akhlak.

Kemudian pada program keputrian evaluasi dilakukan pada minggu kelima 
pada beberapa bulan tertentu. Tetapi pada pelaksanaanya memang, kurang berjalan dengan baik karena kesibukan siswasiswinya. Program menlan berada dibawah tanggung jawab DKM/ rohis SMA Negeri 3 Bandung. Dalam pelaksanaanya kegiatan ini kurang berjalan dengan baik dikarenakan kurang kordinasi antara pembina keputrian dengan pelaksana (WGP2, WP, O6).

Sedangkan pada program manasik haji, pesantren kilat, penyembelihan hewan qurban evaluasi selalu dilaksanakan, karena selalu diminta pertanggungjawaban oleh Depag. Evaluasi yang dilakukan biasanya dalam bentuk laporan pertanggungjawaban (WGP2, WGP3).

Pada program MT PAI, evaluasi dilakukan setiap minggu dengan pementor. Berdasarkan wawancara dengan salah satu pementor evaluasi dilakukan saat Talaqi. Adapun yang dilakukan pada saat talaqi adalah membahas ketercapaian, Controlling,evaluating dan membahas materi. Selain itu, evaluasi juga dilakukan dengan kuisioner. Aspek kuisioner yang dilihat adalah mentor, proses mentoring dan materi. Hasil kuisioner MT PAI SMAN 3 Bandung tahun ajaran 2012/2013 per Oktober 2012 adalah sebagai berikut: 1. Aspek mentor : $53.75 \%$ setuju mentor memberikan materi secara jelas, $41,73 \%$ setujumentor membawakan mentoring dengan asyik, $50,9 \%$ setuju mentor pantas untuk dijadikan teladan, 50,43\% sangat setuju mentor dekat dengan adik mentor. 2. Proses mentoring : 40,2\% setuju acara mentoring bervariasi, $36,91 \%$ setuju terdapat games atau simulasi, 50,11\% sangat setuju mentoring dapat menambah ilmu, $42,88 \%$ setuju mentoring dapat menambah semangat, $47,68 \%$ setuju tempat mentoring nyaman. 3. Materi : $47,63 \%$ tidak setuju materi yang disampaikan berat, 59,19\% setuju materi yang disampaikan sampai ke hati,
$62,18 \%$ setuju materi yang disampaikan aplikatif, 55,05\% ragu-ragu materi sudah diketahui sebelumnya.

\section{Output Pembinaan Akhlak di SMA Negeri 3 Bandung \\ Kompetensi IMTAK di SMA} Negeri 3 Bandung rujukannya kepada rukun Iman dan Islam. Seperti rukun iman pertama yaitu mengucapkan dua kalimat syahadat. Artinya peserta didik di SMAN3 harus bisa membaca atau mengucapkan kalimat syahadat dan mengaplikasikannya. Rukun Islam yang kedua adalah Şalat, di mana peserta didik dituntut untuk bisa membaca al-Qur'ān kemudian bagus bacaannya. Rukun Islam yang ketiga adalah zakat, maka kompetensi yang harus dimiliki peserta didik adalah infaq/shadaqah. Rukun Islam yang ke empat adalah puasa. Dan rukun Islam yang kelima adalah haji, peserta didik dibekali bacaan atau doa haji sebelum akhirnya dikemudian hari ia berhaji. Kompetensi IMTAK yang dimaksud adalah lebih ke arah aplikasi bagaimana kompetensi IMTAK diterapkan di sekolah. Aplikasinya pada pembiasaan harian, mingguan, bulananan dan tahunan. Sehingga dari kompetensi yang diharapkan, indikatornya terdapat pada implementasi kegiatan yang sudah direncanakan oleh sekolah sebagai wujud manifestasi dari upaya peningkatan ketakwaan terhadap Tuhan Yang Maha Esa (WKS).

Selain itu indikator pencapaian tujuan dari pembinaan akhlak yang mana untuk meningkatkan iman dan takwa adalah pada perilaku sehari-harinya. Sikap terhadap guru di sekolah. Sikap dengan sesama teman, dilihat dari apakah saling bertegur sapa, dan sikap dengan kaka kelasnya (WGP1, WGP2).

Menurut teori indikator, indikator merupakan sesuatu yang dapat menunjukkan kinerja dari subkomponen, dan selanjutnya menunjukkan kinerja komponen (Suharsini Arikunto, 2010, 
hlm. 12). Jadi, indikator yang dirumuskan dalam pembinaan akhlak di SMAN 3 Bandung kurang tepat, karena belum menggambarkan pencapaian program yang terukur.

Selain itu, hasil dari pembinaan akhlak yang dilakukan oleh SMA Negeri 3 Bandung terhadap siswanya dapat penulis lihat melalui wawancara dan observasi yang penulis lakukan secara langsung di SMA Negeri 3 Bandung. Observasi yang penulis lakukan adalah dengan cara melihat keseharian kegiatan dan perilaku para siswa selama di sekolah. Seperti sikap yang ditunjukkan oleh para siswa adalah ketika jam istirahat ada beberapa siswa yang melakukan Şalat duha di mesjid. Kemudian hasil wawancara penulis dengan beberapa siswa mengenai hasil pembinaan menunjukkan bahwa banyak yang mengaku ada perubahan secara kognitif yaitu menambah wawasan atau pengetahuan mengenai agama Islam, pengetahuan membaca al-Qur'ān yang baik. Kemudian secara afektif, perubahannya pada peningkatan ibadah, perubahan perilaku ke arah yang lebih baik (WHpS1, WHpS 3, WHpS 4, WHpS 6, WHpS 8, WHpS 9, WHpS 10, WWKs).

\section{KESIMPULAN}

Berdasarkan hasil dan pengolahan data yang telah dipaparkan pada bab sebelumnya, serta hasil analisis pembahasan hasil penelitian, dapat dikemukakan simpulan sebagai berikut.

Visi SMA Negeri 3 Bandung telah sesuai dengan teori. Begitupun dengan misi yang telah ditetapkan oleh sekolah, memenuhi prinsip dari misi yaitu memberikan arah dalam mewujudkan visi, menjadi dasar program pokok sekolah menekankan pada mutu layanan peserta didik dan mutu lulusan yang diharapkan oleh sekolah.

Raw input peserta didik SMAN 3 Bandung dari tahun ke tahun sudah ada pola tersendiri. Adapun kualifikasi akhlak secara tidak langsung masuk penilaian pelajaran PAI dan PKn. Berdasarkan hasil data yang diperoleh materi pada setiap programnya telah disusun dengan baik.

Pada pembinaan akhlak SMAN 3 Bandung, komponen tersebut telah terpenuhi, walaupun dalam realisasinya belum sempurna. Adapun tujuan yang telah dirumuskan adalah untuk meningkatkan iman dan takwa peserta didik. Kemudian dalam pelaksanaannya, pembinaan di SMAN 3 Bandung termasuk ke dalam pembinaan langsung (direct contact) karena pembina atau pendidik melakukan pembinaan dengan tatap muka. Sedangkan pada evaluasi program yang dilakukan di SMAN 3 Bandung, tidak berjalan dengan baik sehingga tidak dapat diukur seberapa jauh tujuan yang tercapai.

Hasil dari pembinaan akhlak dilihat selama masa pendidikan. Dari mulai sikap terhadap guru di sekolah. Sikap dengan sesama teman, dilihat dari apakah saling bertegur sapa, dan sikap dengan kaka kelasnya, peningkatan ibadah dan perubahan perilaku positif peserta didik. Perubahan tidak hanya pada aspek afektif tetapi juga pada aspek kognitif, di mana siswa merasa bertambahnya wawasan mengenai agama Islam, tata cara ibadah. Hanya saja indikator kurang tepat, karena belum menggambarkan pencapaian program yang terukur. 


\section{REFERENSI}

Ahmad, A. (2008). Dasar-Dasar Pendidikan Agama Islam. Jakarta: Sinar Grafika.

Arikunto, S. (2004). Dasar-Dasar Supervisi. Yogyakarta: PT Rineka Cipt.

Muhaimin. (2011). Manajemen Pendidikan. Jakarta: Kencana.

Nasution. (2009). Metode Research. Jakarta: Bumi Aksara.

Nata, A. (2003). Akhlak Tasawuf. Jakarta: PT Raja Grafindo.

Oemar, I. (2013, November 117). kompasiana. Retrieved Februari 10, 2015, from Artikel: www.kompasiana.com

Pidarta, M. (2011). Manajemen Pendidikan Indonesia. Jakarta : Rineka Cipta.

Rahmat, M. (2012). Filsafat Akhlak. Bandung: Value Press.

Ramayulis. (2005). Metodologi Pendidikan Agama Islam. Jakarta: Kalam Mulia.

Somarya, D., \& Nuryani, P. (2010). Landasan Pendidikan. Bandung:
Tim Dosen MKDP Landasan

Pendidikan UPI.

Sugiyono. (2013). Metode Penelitian Kuantitatif, Kualitatif, dan Kombinasi (Mixed Methods). bandung: Alfabeta.

Sukardi. (2013). Metodologi Penelitian Pendidikan. Jakarta: PT Bumi Aksara.

Suprapto, B. (2012, September 22). Kompasiana. Retrieved Februari 10, 2015, from edukasi kompasiana: www.kompasiana.com

Tafsir, A. (2008). Metodologi Pengajaran Agama Islam. Bandung: Remaja Rosdakarya.

Usman, H. (2010). Manajemen Teori, Praktik, dan Riset Pendidikan . Jakarta: Bumi Aksara.

Wahyuni, B. d. (2008). Teori Belajar dan Pembelajaran. Jogjakarta: ARRUZZ MEDIA.

Zahruddin. (2004). Penganter Studi Akhlak. Jakarta: PT RajaGrafindo Persada. 